\title{
Informal Economy and Financial Development in West African Economic and Monetary Union Countries (WAEMU): Role of Institutions
}

\author{
Aicha Tiendrebeogo \\ Department of Economics and Management, University Ouaga II, Ouagadougou, Burkina \\ Email address: \\ aichtie@gmail.com \\ To cite this article: \\ Aicha Tiendrebeogo. Informal Economy and Financial Development in West African Economic and Monetary Union Countries (WAEMU): \\ Role of Institutions. Journal of Business and Economic Development. Vol. 5, No. 3, 2020, pp. 187-198. doi: 10.11648/j.jbed.20200503.19
}

Received: August 17, 2020; Accepted: September 2, 2020; Published: September 19, 2020

\begin{abstract}
Informal economy is highly developed in sub-Saharan African countries, particularly, in West African Economic and Monetary Union Countries (WAEMU). In fact, the size of informal economy has been around 50\% of GDP in recent years, despite the efforts made by international institutions (IMF and the African Union (AU)) to contain its development. It should be noted that informality increase has consequences on economy. On the one hand, a thriving informal economy can cause serious difficulties for policymakers because official indicators on unemployment, labor force, income, and consumption are unreliable. A policy based on wrong official indicators may be ineffective or even worse. On the other hand, a large amount of informality is found to be detrimental to economic growth. Notwithstanding these facts, this large size of informality is accompanied by a financial sector that is struggling to develop, despite the various efforts of the authorities in charge of this sector. Added to this is the low quality of public institutions in these countries. Based on these facts, the aims of this research is to analyze the effect of financial development on the development of informality, but also the non-linear relationship between informal economy, financial development and the quality of institutions, in of the West African Economic and Monetary Union countries (WAEMU), over period of 1991 to 2017. For this purpose, pooled mean group (PMG) model is used to analyze the effect of financial development on the informal economy. And for the non-linear analysis, threshold model specification (Panel Threshold Regression: PTR) is used. The results show that for financial development to contribute to reducing the size of the informal economy, the quality of institutions must reach a threshold of 0.575 on a scale of 0 to 1 . It also shows that real GDP per capita and education attainment have a negative effect on informality. On the other hand, the unemployment rate, the rate of urbanization and the share of agriculture in GDP have a positive effect on informality.
\end{abstract}

Keywords: Informal Economy, Financial Development, Institutions, PMG Estimator, PTR Estimator

\section{Introduction}

Informal economy is an important component of the economy in developing countries. It has become an issue of concern since [26] work on urban economic activities in Ghana and the work of the World Employment Program undertaken by the International Labor Office in the 1970s. It is in this vein that this topic was discussed at the Sixth Ordinary Session of the African Union Commission on Labour and Social Affairs in 2008 in Addis Ababa, Ethiopia. Despite the efforts made by international institutions (IMF and the African Union (AU)) and those of governments, the size of the informal sector remains very high in developing countries, particularly those of the WAEMU $[13,39]$. Indeed, the size of the informal sector represented on average $42.07 \%$ of GDP in 2017 for the zone, according to some author [40]. This large size of informality in developing countries makes authors want to find its determinants. The literature lists several factors that can influence the development of the informal sector. Indeed, the growth of the informal economy is caused by many different factors. The most important and most often cited are: increased taxes [51, 55] and social security contributions; increased regulation of the formal economy [55, 9], particularly of labor markets; forced reduction of weekly working hours; early retirement; unemployment, etc.; and the growth of the informal economy 
[55, 9]. Moreover, other authors $[15,52,53]$, attribute the development of informality to the quality of public institutions. Recently, Authors have shown that the quality of institutions is an important determinant of the development of informality in a country [15, 52]. Also, debates have emerged to shed light on the possible interactions between the financial sector and informality. For some authors, financial development is a means of curbing the expansion of informality, while for others, the financial sector has no effect on the development of the informal sector. Indeed, authors such attribute the growth of the informal economy to the low level of financial development [32, 37]. Indeed, financial sector can bring informal economic units into the formal economy through its services such as the provision of credit with better economic terms and maturities, investment advice and different investment instruments tailored to individual preferences [4]. The development of the financial sector can therefore contribute to reducing the size of the informal economy, to facilitate the monitoring and taxation of transactions. Similarly, other studies reveal that financial sector development induces a reduction in the size of the informal economy $[8,12]$. On the other hand, the authors find that the financial sector has no effect on informality. This is the case of some authors who argue that financial development does not have an effect on informal sector development [30]. These developments lead us to ask the following questions: what is the effect of institutional quality on the size of the informal sector? What is the effect of financial development on the size of the informal sector? And finally, what is the role of institutional quality in the relationship between financial development and the informal sector? This research first makes an economy of the literature, then presents the methodology and finally the results of the study.

\section{Literature}

This literature highlights work that links economic development and informality, the quality of institutions and informality, and informality, financial development and institutions.

\subsection{Informality and Financial Development}

The role of financial development in the development of informality has been debated in both the theoretical and empirical literature. Theatrically, it appears that the supply of credit is low when there is little financial openness or competition in the banking sector [37]. They suggest that reforms aimed at reducing informality by removing barriers to entry or improving enforcement may be more effective in financially liberalized countries. Thus, in countries where financial openness is low, formalizing firms will not guarantee them access to formal credit. Similarly, it exists a theoretical and empirical study of the relationship between financial development and the size of the informal economy [12]. In their theoretical framework, agents allocate investments between a low-performing technology that can be exploited with internal funds and a high-performing technology that requires external financing. Enterprises can reduce the cost of financing by disclosing some or all of their assets and using them as collateral. However, the decision to disclose also involves higher tax payments and reduces tax evasion. They show that financial development (reducing the cost of external finance) can reduce tax evasion and the size of the informal economy. It is demonstrated that a low level of financial development associated with high inflation leads to a larger informal economy and vice versa [7]. Moreover, countries with a high level of financial development will have lower monitoring costs, and vice versa. Borrowers who choose not to report their income to the bank will be subject to higher costs of access and loan conditions.

Empirically some authors develop a dynamic general equilibrium model in which agents avoid taxes by operating in the informal economy. Firms that evade taxes have to take on credit rationing from banks [16]. Simulation of their model using Pakistani data shows that when the government adopts a high tax regime, firms initially enter the informal economy in part; then they gradually return to the formal economy because when they do not pay taxes, their credit is limited and hence the availability of capital. On the other hand, a low tax regime eliminates the informal economy and reduces credit rationing, but it is not sustainable in the long run because overall investment in the economy is reduced due to credit rationing. Also, studies have examined the relationship between the informal economy and financial development in debt markets in Italy over the period 1997-2003 and found that financial sector development did not have a significant effect on the size of the shadow economy, but that the shadow economy hindered financial sector development. They use the following estimation methods: a two-way fixed-effects model, a version of the instrumental variable (IV) and a simultaneous equation model using the triples least squares method. They find that the informal economy has a negative impact on outstanding credit to the private sector [23]. Thus, a $1 \%$ increase in informality leads to a decline of about 2 percentage points in the volume of loans to businesses and 0.3 percentage points in the stock of loans to households. Another, study the relationship between the informal economy and financial development in a model of tax evasion and bank intermediation. In this model, agents with diverse skills apply for loans for investment projects that may prove risky [8]. There is an asymmetry of information between borrowers and lenders. The lenders therefore self-select in a separation equilibrium. This leads borrowers to choose the amount of their income to declare by exchanging their incentives to provide collateral for their disincentives to comply with their tax obligations. The major implication of their analysis is that the marginal benefit of income disclosure increases with the level of financial development. Thus, it appears that low financial development leads to greater tax evasion and a larger informal economy. Others explore the link between the informal economy and the development of the financial sector in Malaysia for the period 1971-2013 [24]. They find that the financial sector can play an important role in reducing the 
informal economy by improving access to finance and the credit market. They also find that in the long run, there is a non-linear relationship between the informal economy and financial sector development in Malaysia, an inverted U-shaped curve, suggesting that a lower (higher) level of financial development corresponds to a higher (lower) level of development of the informal economy.

\subsection{Informality and Institutions}

Theoretically, someone shows that entrepreneurs engage in informality to avoid corruption and the burden of bureaucracy in public administrations [30]. Similarly, another demonstrates that the key determinants of informality are: over-regulation and the inability of the state to protect property rights [56]. Study proposes a model to analyze how institutions, taxation and government regulations affect the productive activity of private firms. One of the model's conclusions is that low quality public institutions increase the size of the informal production and reduce the tax revenue [27]. Empirically, authors examine the impact of public institutions and policies on the size of the informal sector in developing countries. They use OLS and two-stage least squares estimation methods. They find that an appropriate set of policies and institutions can improve income generation in the formal economy at the expense of the informal economy [49]. Labor market regulation and taxation contribute to reducing the informal economy when combined with effective governance. In same way, others used the same method of analysis (MCO), to examine the influence of institutional quality on the development of the underground economy in seven (07) developing countries of the Association of Southeast Asian Nations (ASEAN) over the period 2007-2016. They found that institutional quality is negatively related to the development of the underground economy, with the exception of regulatory quality. The variables of corruption control, political stability and absence of violence, and voice and accountability have a positive influence on reducing the development of the underground economy [38].

\subsection{Informality, Financial Development and Institutions}

Previous studies make the link between institutional quality, financial development and informality. For example, the interaction between the informal economy, financial sector development and institutional quality is examined over the period 2003-2014 in the transition economies of the European Union, using panel data analysis [5]. They used causality test proposed by authors [2-19] and found that there is a cointegrating relationship between the informal economy, financial sector development and institutional quality. In addition, they also find that financial development and institutional quality have a long-term negative impact on the informal economy. On the other hand, some authors found no evidence that financial development has an effect on informality. Indeed, some authors use a simple bi-directional fixed-effects model, an instrumental variable (IV) version and a simultaneous equation model using three-step least squares (3SLS) on panel data from firms in Italy [23]. Among other things, they find that financial deepening has no effect on informality in Italy.

\section{Methodology}

This section proposes the specification of theoretical-empirical model, the variables used and the data source, the estimation techniques, and preliminary tests on the data.

\subsection{The Model}

The literature on the determinants of informal economy is based on the model of an author, which links corruption and the development of the informal sector [57]. Indeed, their model has served as a theoretical and empirical framework [14, 17, 49] with some extensions. Thus, the theoretical analysis function is defined as follows:

$$
I E=f\left(F D_{i}, Z_{i}\right)
$$

Or IE is the size of the informal economy, FD is financial development and a set of variables that influence the informal economy. Specifying the theoretical model described above in panel, the empirical equation to be estimated is as follows:

$$
I E_{\mathrm{it}}=\alpha+F D_{i, t}+\sum_{l=1}^{6} \beta_{j} Z_{l, i t}+\mathcal{E}_{i t}
$$

\subsection{Estimation Methods}

This section presents the linear estimation method, for the analysis of the effects of institutional quality and financial development on the size of the informal economy; and a regime-switching or threshold effect model for determining the relationship between financial development and the informal sector as a function of the level of institutional quality [25].

\subsubsection{Linear Model Estimation}

It is used for the linear analysis, the mean group (MG) or pooled mean group (PMG) estimator [48]. The PMG estimator imposes an equality constraint on the long-term coefficients and allows the short-term coefficients to be different from one country to another. In contrast, the PMG estimator is the unweighted average of the coefficients from the different individual regressions. The fundamental difference between the two estimators is that the MG estimator does not take into account the possibility that some parameters in the groups may be the same.

Referring to model initiator [48]. i.e. a sample of $\mathrm{N}$ individuals observed over T periods, with $(N, T) \in N^{*} N$; the following ARDL (Autoregressive Distributed-lagged model) is considered:

$$
g_{i t}=\lambda_{i j} g_{i, t-1}+\sum_{j=1}^{n} \delta_{i j}^{\prime} X_{i t}^{p}+\gamma_{1 i} V I_{i t}+\mu_{i}+\tau d_{i t}+\varepsilon_{i t}
$$


$i=1,2 \ldots, N ; t=1,2 \ldots, T$

Where $g_{i t}$ is the explained variable, is a matrix of explanatory variables, of format ( $\mathrm{k} \mathrm{X} 1) ; \mu_{i}$ represents the individual fixed effects (countries); $\lambda_{i j}$ are coefficients assigned to the lagged dependent variables $y_{i, t-j}$, and $\delta_{i j}^{\prime}$ is a matrix of scalars of format $(1 \mathrm{X} \mathrm{k})$. If the variables are cointegrated, then the error term $\varepsilon_{i t}$ is a stationary process. In this case, the model can be re-specified as an error-correction model in which the short-term dynamics are influenced by the deviation $\theta_{i}=\theta$ from the long-term relationship:

$$
\Delta \mathrm{g}_{i t}=\varphi_{i}\left(\mathrm{~g}_{i t-1}-\theta_{i}^{\prime} x_{i t}-\delta_{1 i} \mathrm{VI}_{i t-1}\right)-\sum_{j=0}^{n} \delta^{\prime \prime}{ }_{i j} X_{i t}-\Delta \delta_{1 i} \mathrm{VI}_{i t-1}+\mu_{i}+\tau d_{i t}+\varepsilon_{i t}
$$

Where $\theta_{i}$ is the vector of long-term coefficients and $\Delta$ the variation operator between two successive times. The adjustment coefficient $\varphi_{i}$ and the long-term coefficients are the parameters of interest. It is expected that $\varphi_{i}<0$. One of the advantages of ARDL models is that the short and long term multipliers are estimated jointly. In addition, these models allow for variables that can be integrated of different orders, I (0) and I (1), or cointegrated [48]. The PMG estimator allows the short-term coefficients and the adjustment coefficient to vary across countries, but the long-term coefficients are the same for all countries $\left(\theta_{i}=\theta\right)$. It has been shown that imposing the same coefficient for the recall force could lead to biases in the adjustment coefficient [31]. The MG estimator allows for heterogeneity in both short-term parameters and long-term coefficients. The choice between the MG and PMG estimator is made using Hausman test.

\subsubsection{Threshold Effect Model}

This section proposes a multi-regime modelling approach, initially proposed by an author [25], which allows thresholds to be introduced in a static panel regression (Panel Threshold Regression: PTR). In these models, a transition mechanism takes place between the different regimes. This type of model makes it possible not only to determine the number of regimes for a variable, but also to estimate the threshold levels and the marginal impact of that variable.

The general formulation of model applied to this research and satisfying a PTR representation is as follows:

$$
I E_{\mathrm{it}}=\mu_{\mathrm{i}}+\beta_{1}^{\prime} \mathrm{x}_{\mathrm{it}}+\beta_{2}^{\prime} \mathrm{x}_{\mathrm{it}} \mathrm{I}\left(\mathrm{q}_{\mathrm{it}} ; \gamma\right)+\varepsilon_{\mathrm{it}}
$$

Where $I E_{\mathrm{it}}$ is the dependent variable, $\mu_{i}$ the individual fixed effects, $\beta_{1}$ et $\beta_{2}$ the parameter vectors $K \times 1$, $\mathrm{I}\left(q_{i t} ; \gamma\right)$ denotes the transition function associated with the transition variables $\left(I N S T_{i t}\right)$ and a vector of threshold parameters $\gamma ; x_{i t}$; is a vector of the explanatory variables not containing the delayed explained variable; $\mathcal{E}_{i t}$ is error term independently and identically distributed $\left(0 ; \sigma_{\varepsilon}^{2}\right)$. In the latter equation, is the set of variables whose associated coefficients do not change from one regime of another.

The first step is to calculate the threshold value for institutional quality and the second is to determine the number of thresholds or regime changes. This model is first tested for successive candidate values of $\gamma$ by sequential least squares; the one that minimizes the sum of the square of the residuals is chosen as the threshold value of institutional quality and tax revenues around which the regime change takes place [3]. This can be expressed under the following constraint:

$$
\hat{\gamma}=\operatorname{argmin} S_{n}(\gamma)
$$

Following different studies [25-3], critical values are estimated to determine the $95 \%$ confidence interval of the threshold value of institutional quality, according to the relationship:

$$
\Gamma=\{\gamma: L R(\gamma) \leq C(\alpha)\}
$$

$L R(\gamma)$ gives an asymptotic distribution of the likelihood ratio statistic, while showing $95 \%$ of this distribution.

The second step consists in estimating the model for the number and level of threshold selected.

Estimation of Threshold effect model

Inferences on threshold models are related to tests of linearity, determination of the number of regimes and the construction of a confidence interval. The linearity test consists of showing that the threshold is statistically significant, and that the relationship between the variables can be represented in a regime-switching model. This is equivalent to testing in equation (5 and 6) under null hypothesis $H_{0}: \beta_{1}=\beta_{2}$ alternately hypothesis $H_{1}: \beta_{1} \neq \beta_{2}$. The decision is made on the basis of the following likelihood ratio statistic:

$$
L R_{1}=S_{0}-S_{1}\left(\hat{\gamma}_{1}\right) / \hat{\sigma}^{2}
$$

where $S_{0}$ is the sum of the squares of the residuals of the linear model and $S_{1}\left(\hat{\gamma}_{1}\right)$ the sum of the squares of the residuals of the one-threshold model.

The test for determining the number of plans applies in the presence of a proven threshold effect. The test procedure is similar to the linearity test. For example, it is tested whether the model has two regimes or at least three regimes, and so on. The following statistic is constructed: where LR is the sum of the squares of the residuals of the three-regime model. The null hypothesis of a single threshold is rejected in favor of at least two, if the value of is greater than the critical values. The process must continue to determine the maximum number of regimes. When the threshold effect is found and the number of thresholds is determined, thresholds are convergent estimators of true values, and that the asymptotic distribution of thresholds is non-standard [25]. 


\subsection{Preliminary Data Testing}

This part presents the dependency test, unit root test, cointegration test, Hausman specification test.

Dependency test

Previous study explains that not taking into account possible inter-individual dependency in the data generation process can affect stationarity and causality results [41]. To predict this eventuality, we perform different tests, namely the dependency tests.

Table 5 in the Appendix presents the results of the dependency tests (the statistics of the tests for the model residuals $[21,20,46])$. The results of the independence tests at the level of residuals and variables do not make it possible to reject the null hypothesis of independence between individuals in the panel (the probabilities associated with the tests are all greater than 0.05$)$. As a result, stationarity studies are based on first generation tests.

Unit Root Test

The study of long-term relationships on panel data requires the problem of stationarity to be taken into account. To overcome this problem, a series of unit root tests has become a common approach for multivariate analysis on panel data. As the hypothesis of individual dependency has not been accepted, first generation unit root tests will be used.

Table 6 in the Annex presents the results of the unit root tests [29-59]. It can be deduced that the variables IE, AGRI and INST are level stationary. On the other hand, the variables FD, GDP, TAX, TU, TC, and EDU, are non-stationary and integrated of order one (I (1)). It is therefore necessary to verify, if there is a premium on board, a long-term relationship between the dependent variable and the explanatory variables.

Cointegration test

Analogous to time series, the problem of spurious regression arises in the study of panel data. These tests, under the assumption of no cointegration, are based on the residuals of the long-run relationship estimates. Since the results of the dependence tests have concluded that the residuals are independent, the first-generation Pedroni test can be used.

Cointegration tests [44-45] are presented in Table 7 in the Appendix. It should be noted that the hypothesis of non-cointegration is not rejected at the $5 \%$ threshold for the panel v, rho panel, PP panel, ADF panel, PP group and ADF group tests. Only the rho panel test rejects the null hypothesis of non-cointegration. It therefore appears that the variables are cointegrated.

\section{Hausman Test}

The panel therefore contains non-stationary and cointegrated variables. This led us to use a heterogeneous, non-stationary panel estimation model. Use of Pooled Mean Group (PMG) or Mean Group (MG) estimators is recommended for this purpose. These estimation methods are proposed respectively by [47] and [48]. These methods have a comparative advantage over conventional methods because they allow heterogeneity to be introduced into certain coefficients to be estimated. Indeed, PMG method assumes that the long-term coefficients of all countries are not significantly different, but allows the short-term coefficients to be different. As for the MG method, it is used when the long-term coefficients are heterogeneous. The choice between the PMG and MG estimator is made by performing a Hausman specification test. The probabilities of the Hausman statistics for the four (04) model specifications are all above the critical threshold of 0.05 (see Appendix Table 8). The null hypothesis of long-term homogeneity of the variables cannot therefore be rejected. Thus, there are no remarkable long-term differences between the coefficients. The coefficients of the PMG estimator are therefore used because they are more appropriate.

\section{Linearity test result}

The results of the linearity and number of plans tests are presented in Table 9 of the Annex. They show that the assumption of non-linearity is validated, as the probabilities associated with the LR tests are below the critical 5\% threshold. This also implies that there are two regimes in the relationship between the informal economy and financial development, taking into account the level of institutions. It appears, therefore, that there is a given level that the quality of institutions must reach in order for financial development to reduce informality. This threshold is 0.576 . This means that the effect of financial development on informality also depends on the quality of institutions.

\subsection{Empirical Models}

The empirical PMG model to be estimated to analyze the direct effect of financial development on the size of the informal economy is therefore as follows:

$$
\Delta \mathrm{IE}_{i t}=\varphi_{i}\left(\mathrm{IE}_{i t-1}-\theta_{i}^{\prime} x_{i t}-\delta_{1 i} F D_{i t-1}-\delta_{12} \mathrm{Z}_{i t-1}\right)-\sum_{j=0}^{n} \delta^{*^{\prime}}{ }_{i j} X_{i t}-\Delta \delta_{1 i} F D_{i t-1}-\Delta \delta_{12} \mathrm{Z}_{i t-1}+\mu_{i}+\tau d_{i t}+\varepsilon_{i t}
$$

The linearity test shows that there is only one threshold. We can therefore specify the following empirical PTR model to analyze the non-linear effect of financial development on informality:

$$
I E_{\mathrm{it}}=\mu_{\mathrm{i}}+\beta_{1}^{\prime} F D_{\mathrm{it}} \mathrm{I}\left(\mathrm{INST}_{\mathrm{it}} \leq \gamma_{1}\right)+\beta_{2}^{\prime} F D_{\mathrm{it}} \mathrm{I}\left(\mathrm{INS} \mathrm{T}_{\mathrm{it}}>\gamma_{2}\right)+\phi^{\prime} \mathrm{z}_{\mathrm{it}}+\varepsilon_{\mathrm{it}}
$$

IE is the dependent variable represented by the size of the informal sector or informal economy as a percentage of GDP. It is calculated according to the econometric method MIMIC (Multiple Indicators Multiple Causes). An increase in this variable also reflects a relatively larger size of the informal sector in the country. It is one of the most widely used measures and is commonly recognized as reflecting the extent of informality in a country [30, 55, 11, 17, 40, 43, 49, 58]. 
DF: Financial development is the variable of interest. It is represented by the credits granted to the private sector by commercial banks and other financial institutions as a percentage of GDP refer to [10].

INST: represents the institutional variable. The corruption control variable of $\mathrm{KKZ}$ is used in this research. The discussion of the link between corruption and informal sector development in the theoretical literature is not consensual. [50], finds that informality and corruption are substitutable. While [28], argue that corruption between taxpayers and tax officials leads to an underestimation of the tax burden and leakage into the informal sector.

Authors explain that corruption leads to lower tax revenues in the formal economy and a deterioration in the quality of public administration $[1,30,42,21]$. These facts thus discourage the incentive for agents to remain in the formal sector. They conclude that corruption leads to the expansion of the informal sector. Therefore, a negative or positive relationship is expected between corruption control and the size of the informal sector. The institutional data are taken from the World Bank/World Governance Indicators database.

$\mathrm{Z}$ represents a set of variables influencing the size of the informal sector or control variables (real GDP per capita $(\mathrm{GDPh})$ ), domestic credit to the private sector (CI), tax revenue as a percentage of GDP (TAX), urbanization rate (TU), unemployment rate (TC), The share of Agriculture in GDP (AGRI), the level of education approximated by the primary school enrollment rate (EDU). These variables affect size of the informal sector [30, 21, 22, 18, 34, 35]. Data on other variables are from the World Bank's World Development Indicators.

\section{Results}

\subsection{Stylized Facts}

Figure 1 below shows the evolution of financial development, the quality of institutions and the size of the zone's informal economy over the period 1996 to 2017. Financial development and the size of the informal economy in the WAEMU zone are moving in the opposite direction. Indeed, over the period 1991-1993, there was a slight simultaneous decline in the quality of institutions and financial development, accompanied by an increase in the size of the informal sector. Also, over the period 1996 to 2007, financial development improved significantly, accompanied by a slight decline in the size of the informal sector. Over the period 2007-2017, there is a remarkable improvement in financial development accompanied by a notable decline in informality. As for the quality of institutions, it has been on a downward trend throughout the study period. Table 1 presents the results of the descriptive analysis. The table shows that informality is an important part of the economies of the region. In fact, it emerges that the average size of the informal economy in the WAEMU zone represents $40.99 \%$ of GDP. This size varies between $29.4 \%$ and $56.63 \%$ over the period 1996 to 2017 . This is not negligible. Financial development, represented by the credit of financial institutions to the economy, is on average equal to $19.76 \%$ of GDP. This value is quite low in relation to the financing needs of this area. The average per capita income in the zone is 295140.8 Fr CFA. Tax revenue represents on average $13.31 \%$ of GDP. The average unemployment rate in the zone is $3.89 \%$. This rate is relatively low, but does not represent the actual current situation. Indeed, the definition of the unemployment rate used is that of the International Labor Office (ILO), which does not correspond to the realities of developing countries such as those in the zone. The average urbanization rate is $33.97 \%$. The average primary school enrolment rate is $81.23 \%$ over the study period. As for the quality of public institutions, on a scale of 0 to 1 , it is on average equal to 0.47 for the zone.

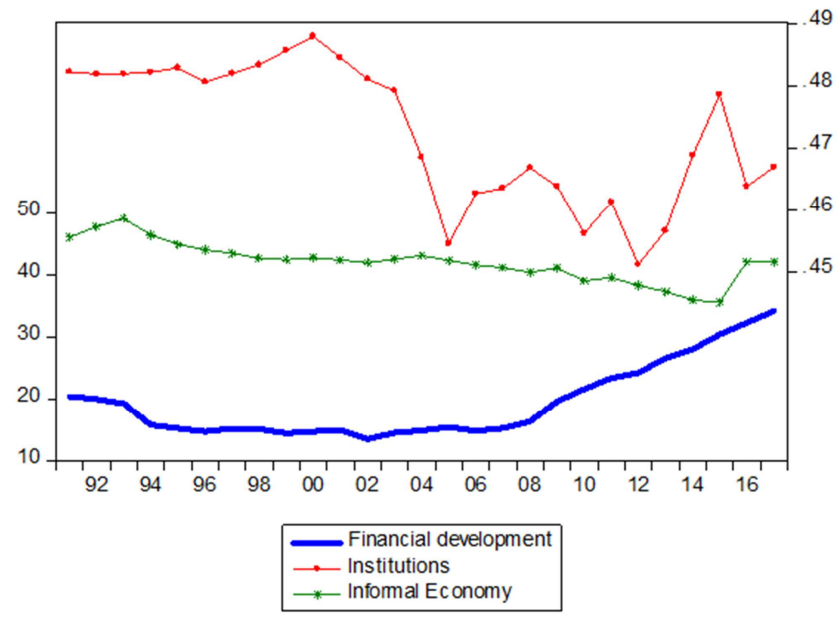

Source: Author based on WDI (2018), WGI (2018), IMF (2018) data

Figure 1. Joint evolution of financial development, the quality of institutions and the informal economy in the zone over the period 1996-2017.

Table 1. Descriptive analysis.

\begin{tabular}{lllll}
\hline Variables & Observations & Moyenne & Ecart Type & Minimum \\
\hline IE & 154 & 40,990 & 6,269 & 29,45 \\
FD & 154 & 19,763 & 9,035 & 3,246 \\
GDP & 154 & 295140,8 & 154819,8 & 130646,9 \\
TAX & 154 & 13,315 & 4,693 & 4,772 \\
TC & 154 & 3,898 & 2,761 & 0,31 \\
TU & 154 & 33,972 & 10,741 & 15,407 \\
AGRI & 154 & 29,753 & 8,338 & 11,979 \\
EDU & 154 & 81,231 & 25,811 & 28,422 \\
INST & 154 & 0,470 & 0,0797 & 5,013 \\
\hline
\end{tabular}

Source: author using data from the FMI (2018), WDI (2018) and WGI (2018). 


\subsection{Effect of Financial Development and Institution Quality on the Informal Economy Size}

This sub-section presents the short- and long-term effects of effect of financial development on the size of the informal economy.

\subsubsection{Short-Term Effect of Financial Development and Institution Quality on the Informal Economy Size}

Table 2 below, shows the short-term results. Specification 1 (column 1) presents the results of financial development effects without taking into account the quality of institutions. The analysis shows that in the short run, financial development has no effect on the size of the informal sector. On the other hand, the coefficient associated with the variable real GDP per capita is negative and significant at the $1 \%$ threshold. This implies that an increase in real GDP per capita leads to a decrease in the size of the informal sector in the short run. It also shows that taxation has a positive and significant effect at the $10 \%$ threshold on the size of the informal economy. Column 2 shows that the quality of institutions has no effect on the size of the informal economy. This is explained by fact that it takes time for institutions to mutate and for economic agents to place their trust in these institutions.

Table 2. Short-term estimate Results.

\begin{tabular}{lll}
\hline \multirow{2}{*}{ VARIABLES } & $\mathbf{1}$ & $\mathbf{2}$ \\
\cline { 2 - 3 } & $\mathbf{S I}$ & $\mathbf{S I}$ \\
\hline Financial Development & -0.0269 & -0.0356 \\
GDP per capita & $(0.0811)$ & $(0.109)$ \\
& $-0.000157^{* * *}$ & $-0.000166^{* * *}$ \\
Fiscality & $(3.78 \mathrm{e}-05)$ & $(3.39 \mathrm{e}-05)$ \\
& $0.250 *$ & 0.288 \\
Unemployment rate & $(0.129)$ & $(0.178)$ \\
& 8.637 & -14.36 \\
Urbanization Rate & $(11.46)$ & $(10.14)$ \\
\multirow{3}{*}{ Education } & 27.95 & 27.40 \\
& $(27.35)$ & $(26.78)$ \\
Agriculture & -0.0300 & 0.118 \\
& $(0.0281)$ & $(0.137)$ \\
Institutions & 0.164 & -0.0704 \\
& $(0.143)$ & $(0.0897)$ \\
\hline
\end{tabular}

Source: author using data from the FMI (2018), WDI (2018) and WGI (2018)

Standard deviations are in brackets

$(*),(* *),(* * *)$ Significant respectively à $10 \%, 5 \%$ and $1 \%$

\subsubsection{Long-Term Effect of Financial Development and Institution Quality on the Informal Economy Size}

Table 4 presents the results of the analysis of the direct effect of financial development on the development of informality in the long run. The coefficient of the error-correction term is negative and significant at the $1 \%$ threshold for both specifications. This shows that the estimation results are valid. Specification 1 (column 1) presents the results of the effects of financial development on the size of the informal sector.
The analysis shows that the coefficient associated with the financial development variable is positive and significant at the $1 \%$ threshold. In other words, if the share of credit granted to the private sector by financial institutions increases, the size of the informal sector also increases. Similarly, the coefficient associated with the unemployment rate is positive and significant at the $10 \%$ threshold. In other words, a $1 \%$ increase in the unemployment rate leads to a $0.55 \%$ increase in the size of the informal sector. Also, the urbanization rate has a positive effect on the size of the informal economy. A $1 \%$ increase in urbanization leads to an increase in informality of $0.009 \%$. Also, the coefficient associated with the agriculture variable is positive and significant at the $10 \%$ threshold. An increase in the share of agriculture in GDP leads to an increase in informality. These positive effects are stable in both specifications. On the other hand, the coefficient associated with real GDP per capita is negative and significant at the $10 \%$ threshold. An increase in real GDP per capita therefore leads to a decrease in informality. This result is consistent with economic theory. Also, the coefficient associated with the education variable is negative and significant at the $1 \%$ threshold. This result is in line with the expected one. An increase in the enrolment rate of $1 \%$ leads to a decrease in informality of $0.18 \%$. It emerges that, contrary to expectations, taxation has no effect on the development of informality in the countries studied. We can therefore state that, contrary to theory, in developing countries such as those in West Africa, taxation is not a source of informality. These negative effects are also stable in both specifications.

The PMG analysis thus shows that the increase in real GDP per capita has a negative effect on the development of informality. This implies that in countries with a high level of development the less informality develops. This is explained by the fact that in the least developed countries, the search for livelihoods leads to the opening of small businesses, taking place on the margins of legislation. This result is consistent with those of several studies [30, 34, 17]. The results of their studies show that economic development, more specifically the increase in real GDP per capita, reduces the development of informality. There is also evidence that education reduces informality. This link is confirmed for the case of Burkina Faso. Indeed, an author used a general equilibrium model and show that the higher an individual's level of education, the less he will engage in informal activities. The results also show that unemployment is a determinant of informality. One of the reasons given for the development of informality is the level of the unemployment rate according to some authors. Authors find empirical evidence to support this hypothesis [58, 17, 49]. We also see that urbanization is a source of informality. This result is consistent in empirical literature [49]. The research also shows that an increase in the share of agriculture in GDP increases the size of informality. This result is consistent with those of an author $[36,58]$.

Column 2 presents the effects of financial development on 
informality, taking into account the quality of institutions. It appears that the coefficient associated with the institution variable is negative and significant at the $1 \%$ threshold. This means that an improvement in the quality of institutions leads to a decrease in informality. This result is confirmed by authors who find that who find that the good quality of institutions reduces the expansion of the informal sector [18, 54]. Recently, it has been shown that poor quality institutions induce the development of informality in ASEAN countries [38]. They also find that when the institution variable is present, the effects of other variables on the informal economy are accentuated.

Table 3. Long-term estimate Results.

\begin{tabular}{lll}
\hline \multirow{2}{*}{ VARIABLES } & $\mathbf{1}$ & $\mathbf{2}$ \\
\cline { 2 - 3 } ec & SI & SI \\
\hline \multirow{3}{*}{ Financial Development } & $-0,501^{* * *}$ & $-0,477^{* * *}$ \\
GDP per capita & $(0,062)$ & $(0,168)$ \\
& $\left(0,288^{* * *}\right.$ & $0,267 * * *$ \\
Taxation & $-8,69 \mathrm{e}-06^{*}$ & $(0,053)$ \\
& $(7,58 \mathrm{e}-06)$ & $\left(6,74 \mathrm{e}-05^{* * *} \mathrm{e}-06\right)$ \\
Unemployment rate & $-0,0067$ & $-0,171$ \\
& $(0,152)$ & $(0,153)$ \\
Urbanization Rate & $0,558^{*}$ & $0,859^{* *}$ \\
\multirow{2}{*}{ Education } & $(0,370)$ & $(0,415)$ \\
& $0,0098^{*}$ & $0,677^{* *}$ \\
Agriculture & $(0,252)$ & $(0,279)$ \\
& $-0,180^{* * *}$ & $-0,178^{* * *}$ \\
Institutions & $(0,0513)$ & $(0,045)$ \\
& $0,058^{*}$ & $0,395^{* * *}$ \\
Constant & $(0,104)$ & $(0,089)$ \\
& & $-30,83^{* * *}$ \\
\hline
\end{tabular}

Source: author using data from the FMI (2018), WDI (2018) and WGI (2018)

Standard deviations are in brackets.

$(*),(* *),(* * *)$ Significant respectively à $10 \%, 5 \%$ and $1 \%$.

\subsection{Non-linear Effect of Financial Development on Informal Economy: The Role of Institutional Quality}

Table 4 presents the non-linear effects of financial development on the size of the informal economy through the quality of institutions. The estimation shows that there is a level of institutional quality where financial development and the size of informality have a negative relationship. Above this threshold there is a positive relationship between the two. This shows the need for non-linear exploration. As theory predicts, access to finance should reduce informality, because access to financial services imposes preconditions on entrepreneurs. For example, access to finance requires firms to declare their activities, register, keep accounting records and be willing to pay taxes. This is because improving the quality of institutions has an effect on both informality [18] and financial development [33]. But in the previous analysis (direct effect), financial development was found to have a positive effect on informality. But this non-linear effects analysis shows us that there is a precondition for financial development to reduce informality. This prerequisite is the quality of institutions.
Improving the quality of institutions by boosting the level of financial development allows financial development to reduce the size of informality.

Table 4. Result of the estimation of the PTR model.

\begin{tabular}{ll}
\hline \multirow{2}{*}{ VARIABLES } & $\mathbf{( 1 )}$ \\
\cline { 2 - 2 } EI \\
\hline GDP per capita & $-4,04 \mathrm{e}-05^{* * *}$ \\
Taxation & $(9,27 \mathrm{e}-06)$ \\
& $-0,369^{* * *}$ \\
Urbanization Rate & $(0,075)$ \\
& $-0,126$ \\
Unemployment rate & $(0,102)$ \\
& $0,664^{* * *}$ \\
Agriculture & $(0,144)$ \\
& $-0,068$ \\
Education & $(0,058)$ \\
& $-0,030$ \\
FD (IN S T $\leq \hat{\gamma})$ & $(0,028)$ \\
& $0,218^{* * *}$ \\
FD (INST $>\gamma)$ & $(0,039)$ \\
& $-0,029^{*}$ \\
Constant & $(0,069)$ \\
& $65,23^{* * *}$ \\
Observations & $(3,513)$ \\
Number of pays & 189 \\
R-squared & 7 \\
\hline
\end{tabular}

Source: author using data from the FMI (2018), WDI (2018) and WGI (2018).

Standard deviations are in brackets.

$(*),(* *),(* * *)$ Significant respectively à $10 \%, 5 \%$ and $1 \%$.

\section{Conclusion}

The objective of this research was to determine the relationship (direct and non-direct) between financial development and that of informality in the WAEMU zone, with the hypothesis that the latter can be affected by the level of institutional quality. The observations cover the period 1996-2017. As the results of the dependency tests showed inter individual independence, we stuck to the first generation stationarity tests, which shows that some variables in the study are not level-stationary, we then carried out a first generation cointegration test [44]. The results of the latter show that the variables used are cointegrated. These results of the tests on the data thus led us to estimate our direct relationship using the pooled mean group (PMG) method. And for the non-linear analysis between finance and informality conditioned by the quality of institutions, we opt for a regime change model.

Our results show that an increase in real GDP per capita, an improvement in the level of education and in the quality of institutions is a brake on the development of informality. On the other hand, an increase in the unemployment rate, the urbanization rate, the share of agriculture in the GDP increases the size of informality. As far as financial development is concerned, its effect depends on the quality of institutions. Indeed, in order for financial development to curb the development of the informal economy, the quality of institutions should reach a minimum level of 0.575 on a scale of 0 to 1 , otherwise it has a positive effect on informality. This 
result is corroborated by [5], who find that financial development associated with good quality institutions hinders

the development of informality.

\section{Appendices}

Table 5. Résultat de l'analyse de dépendance.

\begin{tabular}{lll}
\hline Test & Statistiques & P-value \\
\hline Specification 1 & & - \\
Frees CD & 0,357 & 0,925 \\
Friedman CD & 33,874 & 0,075 \\
Pesaran CD & 3,686 & - \\
Specification 2 & & 0,135 \\
Frees CD & 0,396 & 0,075 \\
Friedman CD & 23,622 & \\
Pesaran CD & 3,647 & \\
\hline
\end{tabular}

Source: author using data from WDI (2018), IMF (2018).

Table 6. Unit root test results.

\begin{tabular}{|c|c|c|c|c|}
\hline \multirow{2}{*}{ Variables } & \multicolumn{2}{|l|}{ level } & \multicolumn{2}{|c|}{ First Difference } \\
\hline & IPS & LLC & IPS & LLC \\
\hline \multirow{2}{*}{ IE } & $-1,397^{*}$ & $-2,003 * *$ & $-3,396 * * *$ & $-12,452 * * *$ \\
\hline & $(0,0812)$ & $(0,022)$ & $(0,000)$ & $(0,000)$ \\
\hline \multirow[t]{2}{*}{ FD } & 5.752 & 4.969 & $-2.341 * * *$ & $-4.232 * * *$ \\
\hline & $(1.000)$ & $(1.000)$ & $(0.009)$ & $(0.000)$ \\
\hline \multirow[t]{2}{*}{ INST } & $-1.287^{*}$ & $-2.106^{*}$ & $-3.655 * * *$ & $-5.437 * * *$ \\
\hline & $(0,098)$ & $(0.017)$ & $(0.000)$ & $(0.000)$ \\
\hline \multirow{2}{*}{$\mathrm{PIBh}$} & $-3,517$ & $-1,427$ & $-8,62831 * * *$ & $-6,244 * * *$ \\
\hline & $(0,999)$ & $(0,923)$ & $(0,000)$ & $(0,000)$ \\
\hline \multirow{2}{*}{ TAX } & 4,216 & 2,57839 & $-5,22673$ & $-9,029 * * *$ \\
\hline & $(1,000)$ & $(0,9950)$ & $(0,000)$ & $(0,0000)$ \\
\hline \multirow[t]{2}{*}{ EDU } & 0,81106 & $-2,135 * *$ & $-2,13472 * * *$ & $-2,85798 * * *$ \\
\hline & $(0,7913)$ & $(0,0311)$ & $(-2,1347)$ & $(0,002)$ \\
\hline \multirow{2}{*}{$\mathrm{TU}$} & 3,93916 & 15,849 & $-3,58873 * * *$ & $-1,838 * *$ \\
\hline & $(1,0000)$ & $(1,000)$ & $(0,000)$ & $(0,033)$ \\
\hline \multirow{2}{*}{$\mathrm{TC}$} & $-0,02046$ & 0,142 & $-3,51965 * * *$ & $-4,782 * * *$ \\
\hline & $(0,4918)$ & $(0,556)$ & $(0,000)$ & $(0,000)$ \\
\hline \multirow{2}{*}{ AGRI } & $-2,389 *$ & $-3,082 * *$ & $-6,432 * * *$ & $-7,964 * * *$ \\
\hline & 0,0084 & $(0,0010)$ & $(0,0000)$ & $(0,0000)$ \\
\hline
\end{tabular}

Source: author using data from WDI (2018), IMF (2018) WGI (2018).

Les écart-types sont entre parenthèses.

$(*),(* *),(* * *)$ Significatif respectivement à $10 \%, 5 \%$ et $1 \%$.

Table 7. Result of the cointegration test.

\begin{tabular}{|c|c|c|}
\hline Statistiques & Valeur & Valeur de p \\
\hline \multicolumn{3}{|c|}{ Specification 1} \\
\hline Panel v & $-1,604$ & 0,005 \\
\hline Panel rho & 3,062 & 0,008 \\
\hline Panel PP & $-3,246$ & 0,000 \\
\hline Panel ADF & $-1,703$ & 0,044 \\
\hline Group rho & 4,093 & 1,000 \\
\hline Group PP & $-4,858$ & 0,000 \\
\hline Group ADF & $-0,973$ & 0,015 \\
\hline \multicolumn{3}{|c|}{ Specification 2} \\
\hline Panel v & $-1,684$ & 0,004 \\
\hline Panel rho & 2,749 & 0,037 \\
\hline Panel PP & $-5,709$ & 0,000 \\
\hline Panel ADF & $-3,939$ & 0,000 \\
\hline Group rho & 3,536 & 0,999 \\
\hline Group PP & $-5,126$ & 0,000 \\
\hline Group ADF & $-2,759$ & 0,003 \\
\hline
\end{tabular}

Source: author using data from WDI (2018), IMF (2018) WGI (2018).

Les écart-types sont entre parenthèses.

$(*),(* *),(* * *)$ Significant respectively $10 \%, 5 \%$ and $1 \%$. 
Table 8. Hausman test result.

Spécification 1

\begin{tabular}{lllll}
\hline & mg & pmg & Difference & S. E. \\
\hline FD & 0.1097 & -0.581 & 0.691 & 1.116 \\
GDPh & -0.0009 & $5.07 \mathrm{e}-06$ & -.0009 & .0003 \\
TAX & 0.419 & 0.7836 & -0.364 & 3.530 \\
TC & -5.429 & 2.983 & -8.413 & 24.065 \\
TU & 0.259 & -0.8479 & 1.107 & 9.777 \\
EDU & -0.219 & -0.0506 & -0.169 & 0.6598 \\
Agri & -0.1256 & 0.0257 & -0.135 & 1.945 \\
Test: & Ho: & difference in coefficients not systematic & & \\
& chi2 $(5)=(b-B) '\left[\left(V_{-} \text {b-V_B }\right)^{\wedge}(-1)\right](b-B)=1.17$ & & \\
& Prob>chi2=0.9481 & & \\
\hline
\end{tabular}

Source: author using data from WDI (2018), IMF (2018) and WGI (2018).

Specification 2

\begin{tabular}{lllll}
\hline Variables & mg & pmg & Difference & S, E, \\
\hline FD & 0,493 & 0,3195 & 0,174 & 0,4562 \\
GDP & $-0,0007$ & 0,0002 & $-0,0001$ & 0,0002 \\
TAX & 1,060 & 0,0447 & 1,016 & 2,187 \\
TC & 20,948 & $-1,214$ & 22,163 & 55,413 \\
TU & 2,325 & 0,582 & 1,743 & 4,998 \\
EDU & $-0,499$ & $-0,188$ & $-0,311$ & 0,412 \\
AGRI & -0.356 & 0.0452 & -0.156 & 1.757 \\
INST & 5,050 & $-35,634$ & 40,683 & 102,979 \\
Test: & Ho: & difference in coefficients not systematic & \\
& chi2 $(7)=(\text { b-B })^{\prime}\left[\left(V_{-} b-V_{-} B\right)^{\wedge}(-1)\right](b-B)=4,22$ & \\
\end{tabular}

Source: author using data from WDI (2018), IMF (2018) and WGI (2018).

Table 9. Linearity test result.

\begin{tabular}{ll}
\hline $\mathbf{9 g}$ & EI \\
\hline Interaction variables & \\
\hline Two regimes (single threshold) & 0,576 \\
Threshold $\hat{\gamma}_{1}$ & {$[0,571 ; 0,576]$} \\
IC $(95 \%)$ & $26,39(0,0067)$ \\
LR-test (p-value) & \\
three regimes (double threshold) & 0,419 \\
Threshold $\hat{\gamma}_{2}$ & {$[0,418 ; 0,419]$} \\
IC $(95 \%)$ & $4,92(0,7633)$ \\
LR-test (p-value) & \\
\hline
\end{tabular}

Source: author using data from WDI (2018), IMF (2018).

\section{References}

[1] Baccaro, L., \& Rei, D. (2005). Institutional determinants of unemployment in OECD countries: A time series cross-section analysis (1960-98).

[2] Basher, S., \& Westerlund. (2009). Panel Cointegration and the Monetary Exchange Rate Model. Economic Modelling, 26 (2), 506-513.

[3] Bayale, N. (2018). Aide et Croissance dans les pays de l'Union Economique et Monétaire Ouest Africaine (UEMOA): retour sur une relation controversée [Aid and Growth in West African Economic and Monetary Union (WAEMU) countries: a return back to a controversial relationship]. University Library of Munich, Germany, No. 85357.

[4] BAYAR, Y., \& AYTEMIZ, L. (2017). Financial Development and Shadow Economy in Turkey. Unregistered Employment, 170.
[5] BAYAR, Y., \& OZTURK, O. F. (2016). Financial Development and Shadow Economy in European Union Transition Economies. Managing Global Transitions: International Research Journal, 14 (2).

[6] BIT. (1972). Employment, Incomes and Equality. A Strategy for increasing productive Employment in Kenya. OIT, Genève.

[7] Bittencourt, M., Gupta, R., \& Stander, L. (2014). Tax evasion, financial development and inflation: Theory and empirical evidence. Journal of Banking \& Finance. 41, 194-208.

[8] Blackburn, K., Bose, N., \& Capasso, S. (2012). Tax evasion, the underground economy and financial development. Journal of Economic Behavior \& Organization, 83 (2), 243-253.

[9] Bosch, G., \& Lehndorff, S. (1998). Arbeitszeitverkürzung und Beschäftigung: Erfahrungen in Europa und wirtschaftspolitische Empfehlungen. Vierteljahrshefte zur Wirtschaftsforschung, 67 (4), 300-325. 
[10] Bose, N., Capasso, S., \& Wurm, M. A. (2012). The impact of banking development on the size of shadow economies. Journal of Economic Studies.

[11] Botero, J. C., Djankov, S., \& La, P. R. (2004). The regulation of labor. The Quarterly Journal of Economics, 119 (4), 1339-1382.

[12] Capasso, S., \& Jappelli, T. (2013). Financial development and the underground economy. 101, 167-178.

[13] Charmes, J. (2002). Les origines du concept de secteur informel et la récente définition de l'emploi informel. Banque Mondiale.

[14] Choi, J. P., \& Thum, M. (2005). Corruption and the shadow economy. International Economic Review, 46 (3), 817-836.

[15] Chong, A., \& Gradstein, M. (2007). Inequality and institutions. The Review of Economics and Statistics, 89 (3), 454-465.

[16] Dabla-Norris, E. R., \& Feltenstein, A. (2005). The underground economy and its macroeconomic consequences. The journal of policy reform, 8 (2), 153-174.

[17] Dreher, A., \& Schneider, F. (2010). Corruption and the shadow economy: an empirical analysis. Public Choice, 144 (1-2), 215-238.

[18] Dreher, A., Kotsogiannis, C., \& McCorriston, S. (2009). How do institutions affect corruption and the shadow economy? International Tax and Public Finance, 16 (6), 773.

[19] Dumitrescu, E., \& Hurlin, C. (2012). Testing for Granger Non-Causality in Heterogeneous Panels. Economic Modelling, 29 (4), 1450-1460.

[20] Frees, E. (s. d.). Assessing cross-sectional correlation in panel data. Journal of econometrics, 69 (2), 393-414.

[21] Friedman, M. (1937). The use of ranks to avoid the assumption of normality implicit in the analysis of variance. Journal of the american statistical association, 32 (200), 675-701.

[22] Galli, R., \& Kucera, D. (2004). Labor standards and informal employment in Latin America. World Development, 32 (5), 809-828.

[23] Gobbi, G., \& Zizza, R. (2007). Does the underground economy hold back financial deepening? Evidence from the Italian credit market. Evidence from the Italian Credit Market (November 2007). Bank of Italy Temi di Discussione (Working Paper) (646).

[24] Habibullah, M. S., Din, B. H., Yusof-Saari, M., \& Baharom, A. H. (2016). Shadow economy and financial sector development in Malaysia. International Journal of Economics and Financial Issues, 6 (7S), 181-185.

[25] Hansen, B. E. (1999). Threshold effects in non-dynamic panels: Estimation, testing, and inference. Journal of econometrics, 93 (2), 345-368.

[26] Hart, K. (1973). Informal income opportunities and urban employment in Ghana. The journal of modern African studies, 11 (1), 61-89.

[27] Hibbs, J., Douglas, A., \& Piculescu, V. (2005). Institutions, corruption and tax evasion in the unofficial economy. Institutions (08), 02c3.

[28] Hindriks, K. V., \& Meyer, J. J. (1999). Agent programming in
3APL. Autonomous Agents and Multi-Agent Systems. 2 (4), 357-401.

[29] Im, K. S., Pesaran, M. H., \& Shin, Y. (2003). Testing for unit roots in heterogeneous panels. Journal of econometrics, 115 (1), 53-74.

[30] Johnson, S., Kaufmann, D., \& Zoido-Lobatón, P. (2000). Corruption, public finances and the unofficial economy. World Bank Publications, 2169.

[31] Kiviet, J. F. (1995). On bias, inconsistency, and efficiency of various estimators in dynamic panel data models. Journal of econometrics, 68 (1), 53-78.

[32] Koeda, J. \&.-N. (2008). Informality and bank credit: Evidence from firmlevel data. International Monetary Fund (8-94).

[33] Kose, M. A., Prasad, E., Rogoff, K., \& Wei, S. J. (2009). Financial globalization: a reappraisal. IMF Staff papers, 56 (1), $8-62$.

[34] Lederman, D., Loayza, N. V., \& Soares, R. R. (2005). Accountability and corruption: Political institutions matter. Economics \& politics, 17 (1), 1-35.

[35] Leenhardt, B. (2005). Le poids de l'informel en UEMOA, premières leçons en termes de comptabilité nationale des enquêtes 1-2-3 de 2001-2003. AFD, Jumbo-Rapport thématique, 8,30 .

[36] Loayza, N. (1996). The economics of the informal sector: a simple model and some empirical evidence from Latin America. The World Bank.

[37] Massenot, B., \& Straub, S. (2011). Informal sector and economic growth: the supply of credit channel.

[38] Maulida, R. H., \& Darwanto, D. (2018). Analysis of Institutional Quality Influence on Shadow Economy Development. JEJAK: Jurnal Ekonomi dan Kebijakan, 11 (1), 49-61.

[39] Mbaye, A. A. (2017). Secteur informel, emplois et transformation structurelle. Document de l'Organisation de la Francophonie, 2-7.

[40] Medina, L., \& Schneider, F. (2018). Shadow economies around the world: what did we learn over the last 20 years? IMF Working Papers.

[41] Niang, A. (2011). Naam: Ideology as State History. Thesis, University of Edinburgh.

[42] Olson, M. (1982). The rise and fall of nations. New Haven.

[43] Ouédraogo, I. M. (2017). Governance, corruption, and the informal economy. Modern Economy, 8 (02), 256.

[44] Pedroni, P. (1999). Critical values for cointegration tests in heterogeneous panels with multiple regressors. Oxford Bulletin of Economics and statistics, 61 (S1), 653-670.

[45] Pedroni, P. (2004). Panel cointegration: asymptotic and finite sample properties of pooled time series tests with an application to the PPP hypothesis. Econometric theory, 20 (3), 597-625.

[46] Pesaran, H. M. (2004). General Diagnostic Tests for Cross Section Dependence in Panels. Cambridge University Working Paper, 0435. 
[47] Pesaran, M. H. (1995). Estimating long-run relationships from dynamic heterogeneous panels. Journal of econometrics, 68 (1), 79-113.

[48] Pesaran, M. H., \& Smith, R. P. (1999). Pooled mean group estimation of dynamic heterogeneous panels. Journal of the American Statistical Association, 94 (446), 621-634.

[49] Rei, D., \& Bhattacharya, M. (2008). The impact of institutions and policy on informal economy in developing countries: an econometric exploration. Geneva: ILO.

[50] Rose-Ackerman, S. (1998). Corruption et développement, En Conférence annuelle de la Banque mondiale sur l'économie du développement 1997. Washington DC: Banque mondiale, 35-37.

[51] Schneider, F. \& Neck, R. (1993). The development of the shadow economy under changing tax systems and structures: some theoretical and empirical results for Austria. FinanzArchiv/Public Finance Analysis, 344-369.

[52] Schneider, F., \& Badekow, H. A heart for illegal workers. Why the shadow economy increases our prosperity. Berlin: Econ.

[53] Schneider, F. (2010). The influence of public institutions on the shadow economy: An empirical investigation for OECD countries. Review of Law \& Economics, 6 (3), 441-468.
[54] Schneider, F., \& Buehn, A. (2012). Shadow economies in highly developed OECD countries: What are the driving forces?

[55] Schneider, F., \& Enste, D. H. (2000). Shadow economies: size, causes, and consequences. Journal of economic literature, 38 (1), $77-114$

[56] Schneider, F., \& Klinglmair, R. (2004). Shadow economies around the world: what do we know?

[57] Shleifer, A., \& Vishny, R. W. (1993). Corruption. The quarterly journal of economics. 108 (3), 599-617.

[58] Torgler, B., \& Schneider, F. (2009). The impact of tax morale and institutional quality on the shadow economy. Journal of Economic Psychology, 30 (2), 228*245.

[59] Levin, A., Lin, C.-F., \& Chu, C.-S. J. (2002). Unit root tests in panel data: asymptotic and finite-sample properties. Journal of econometrics, 108 (1), 1-24.

[60] Traore, A., \& Ouedraogo, I. (2016). Public policies promoting the informal economy: effects on incomes, employment and growth in Burkina Faso. 